\title{
Bacillus subtilis Mediated Systemic Resistance in Chillies against Colletotrichum capsici
}

\author{
B. Meena* \\ Regional Research Station, Tamil Nadu Agricultural University, Vridhachalam - 606001 , \\ Tamil Nadu, India \\ *Corresponding author
}

\section{A B S T R A C T}

\begin{tabular}{|l|}
\hline K e y w o r d s \\
$\begin{array}{l}\text { Chillies, Colletotrichum } \\
\text { capsici, Bacillus subtilis, } \\
\text { ISR }\end{array}$ \\
\hline Article Info \\
\hline $\begin{array}{l}\text { Accepted: } \\
12 \text { April } 2018 \\
\text { Available Online: } \\
\text { 10 May } 2018\end{array}$ \\
\hline
\end{tabular}

\section{Introduction}

Chilli (Capsicum annuum L.) is an important commercial vegetable crop grown for domestic and export markets. Among the various biotic factors affecting chilli, fruit rot and die back caused by Colletotrichum capsici (Syd.) Butl. and Bisby is one of the serious diseases of chillies and occurs in severe form in all the southern states of India. The loss in yield was estimated as 30.7 per cent in Tamil Nadu. Use of chemicals against plant diseases leads to environmental pollution and toxic effects on human health and give possibility to pathogens for building-up resistance to chemicals. Hence biological control agents creating a longer lasting effect are a necessity
Die-back and fruit rot caused by Colletotrichum capsici (Syd.) Butl. and Bisby is the destructive disease in chillies. The effect of Bacillus subtilis talc based formulation in managing the fruit rot disease and inducing resistance in chillies was investigated. $B$. subtilis strain $B s 1$ significantly inhibited the growth of $C$. capsici in vitro. Seed treatment with B. subtilis@10 g/kg seed followed by foliar application of B. subtilis @ $10 \mathrm{~g} / \mathrm{l}$ on 30 60 DAP was effective in managing the fruit rot disease and increasing the dry chillies yield under field conditions. The effect of biocontrol agent B. subtilis on the induction of defense enzymes viz., chitinase and $\beta$-1,3-glucanase in chilli plants infected with $C$. capsici was investigated. There was a marked increase in the induction of defense compounds in response to pathogen inoculation in $B$. subtilis treated chilli leaves. 
the present study was undertaken to evaluate the bioagent, $B$. subtilis on the management of die-back and fruit rot of chillies and induction of defense enzymes.

\section{Materials and Methods}

\section{Isolation of pathogen}

The pathogen Colletotrichum capsici was isolated from a fruit rot infected chillies and maintained on potato dextrose agar (PDA) slants (Rangaswami, 1972).

In vitro screening of Bacillus subtilis against Colletotrichum capsici

Using Nutrient Agar medium, B. subtilis isolates were isolated from the rhizosphere of various crop plants. The antagonistic potential of biocontrol agents against $C$. capsici was tested by dual culture method on PDA medium (Dennis and Webster, 1971).

A $9 \mathrm{~mm}$ actively growing culture disc of pathogen and antagonists were separately placed or streaked opposite to each other on sterilized PDA medium under aseptic conditions. The medium inoculated with pathogen alone served as the control. The radial growth of the pathogen was measured after seven days of incubation. Four replications were maintained.

\section{Field studies}

A talc-based powder formulation of B. subtilis was developed as described by Vidhyasekaran and Muthamilan (1995). Field eperiment was conducted in the farmers field at Thondamuthur, Coimbatore District, Tamil Nadu on the management of fruit disease of chillies. The seeds of chillies were treated with B. subtilis talc formulation at the rate of $10 \mathrm{~g}$ per $\mathrm{kg}$ of seed before sowing. Soil application of B. subtilis talc formulation at the rate of 2.5 kg/ha mixed with neem cake @ 250 kg/ha was done during the time of field preparation. Foliar application with $B$. subtilis talc formulation was done at $10 \mathrm{~g}$ per litre on 30 and 60 days after planting.

The combination treatment of seed treatment and and foliar application with bioagent, $B$. subtilis was also made. For comparison, the seeds were treated with fungicide carbendazim at the rate of $2 \mathrm{~g}$ per $\mathrm{kg}$ of seed.

Foliar application with carbendazim at $1 \mathrm{~g}$ per litre was also done on 30 and 60 days after planting. The combination of seed treatment with carbendazim at the rate of $2 \mathrm{~g}$ per $\mathrm{kg}$ of seed followed by foliar application with carbendazim at $1 \mathrm{~g}$ per litre was also done on 30 and 60 days after planting. The fruit root disease intensity was observed in scale 0-9 rating at the time of harvest by random selection of 25 plants per plot.

Per cent disease index (PDI) was calculated using the formula

Sum of numerical ratings
PDI = -------------------------- x 100
Number of plants observed x Maximum grade

The yield of dry chillies was also recorded for each treatment and the data were statistically analyzed.

\section{Induction of defense compounds in chillies due to foliar application of $B$. subtilis}

Chilli plants grown in pots were sprayed with B. subtilis talc formulation at $10 \mathrm{~g}$ per litre at 45 days after planting and challenge inoculated with $C$. capsici at 47 days after planting. At various times after application, leaf samples were collected at 1, 3, 5 and 7 days after pathogen inoculation to assay the change in activities of defense related enzymes viz., chitinase and $\beta$-1,3-glucanase. 


\section{Assay of chitinase}

The colorimetric assay of chitinase was carried out as per Boller and Mauch (1988). One gram of sample was extracted with $5 \mathrm{ml}$ of $0.1 \mathrm{M}$ sodium citrate buffer ( $\mathrm{pH}$ 5.0). The homogenate was centrifuged at $10,000 \mathrm{rpm}$ for $10 \mathrm{~min}$ at $4^{\circ} \mathrm{C}$ and the supernatant was used as enzyme source. The reaction mixture consisted of $10 \mu \mathrm{l}$ of $0.1 \mathrm{M}$ sodium acetate buffer ( $\mathrm{pH} 4.0), 0.4 \mathrm{ml}$ enzyme source and 0.1 $\mathrm{ml}$ colloidal chitin $(10 \mathrm{mg})$. After incubation for $2 \mathrm{~h}$ at $37^{\circ} \mathrm{C}$, the reaction was stopped by centrifugation at 3,000 rpm for $3 \mathrm{~min}$. An aliquot of the supernatant $(0.3 \mathrm{ml})$ was pipetted into a glass reagent tube containing $30 \mu \mathrm{l}$ of $1 \mathrm{M}$ potassium phosphate buffer $(\mathrm{pH}$ 7.0) and incubated with $20 \mu \mathrm{l}$ of $3 \%(\mathrm{w} / \mathrm{v})$ snail gut enzyme for $1 \mathrm{~h}$. Later, the reaction mixture was brought to $\mathrm{pH} 8.9$ by the addition of $70 \mu \mathrm{l} 0.1 \mathrm{M}$ sodium borate buffer ( $\mathrm{pH} 9.8$ ). The mixture was incubated in a boiling water bath for $3 \mathrm{~min}$ and rapidly cooled. After addition of $2 \mathrm{ml}$ of para-dimethyl aminobenzaldehyde (DMAB), the mixture was incubated for $20 \mathrm{~min}$ at $37^{\circ} \mathrm{C}$ and the absorbance was measured at $585 \mathrm{~nm}$. Nacetylglucosamine (GlcNAc) was used as a standard and the enzyme activity was expressed as nmol GlcNAc equivalents $\min ^{-1}$ $\mathrm{g}^{-1}$ of fresh tissue.

\section{Assay of $\beta$-1,3-glucanase}

One gram of sample was extracted in $5 \mathrm{ml}$ of $0.05 \mathrm{M}$ sodium acetate buffer $(\mathrm{pH} 5.0)$. The homogenate was centrifuged at $10,000 \mathrm{~g}$ for $10 \mathrm{~min}$. at $4^{\circ} \mathrm{C}$ and the supernatant was used as enzyme source. $\beta-1,3$-glucanase activity was assayed by the laminarin-dinitrosalicylic acid method (Pan et al., 1991). The reaction mixture consisted of $62.5 \mu \mathrm{l}$ of $4 \%$ laminarin and $62.5 \mu \mathrm{l}$ of enzyme source. The reaction was carried out at $40^{\circ} \mathrm{C}$ for $10 \mathrm{~min}$ and stopped by adding $375 \mu \mathrm{l}$ of dinitrosalicylic acid and heating for $5 \mathrm{~min}$ in boiling water.
The absorbance was measured at $500 \mathrm{~nm}$ and the enzyme activity was expressed as nmol GlcNAc equivalents $\min ^{-1} \mathrm{~g}^{-1}$ of fresh tissue.

\section{Results and Discussion}

Among the various strains of $B$. subtilis tested against the pathogen in vitro, the strain $B s 1$ was the most effective one in inhibiting the fungal growth of $C$. capsici by recording least mycelial growth of $3.4 \mathrm{~cm}$ (Table 1). The strain $B s 2$ was found to be the least effective in inhibiting the growth of C. capsici $(6.1 \mathrm{~cm})$. The maximum mycelial growth of $8.8 \mathrm{~cm}$ was observed in the control (Table 1). Meena and Marimuthu (2012) reported that $P$. fluorescens inhibited the growth of Sclerotium rolfsii in vitro effectively.

The results of the field experiments conducted on the management of fruit rot disease of chillies showed that seed treatment with $B$. subtilis @10 g/kg seed followed by foliar application of B. subtilis @ $10 \mathrm{~g} / \mathrm{l}$ on 30 and 60 DAP was effective in managing the fruit rot disease which recorded the lowest disease intensity of 23.6 PDI. It was found to be on par with seed treatment with carbendazim at 2 $\mathrm{g}$ per $\mathrm{kg}$ seed followed by foliar application of carbendazim at $1 \mathrm{~g}$ per litre on 30 and 60 days after planting which recorded disease intensity of 24.7 PDI. Seed treatment alone with $B$. subtilis @ $10 \mathrm{~g} / \mathrm{kg}$ seed recorded the disease intensity of 31.8 PDI. The disease intensity of 32.3 PDI was observed in streatment alone with carbendazim at $2 \mathrm{~g}$ per $\mathrm{kg}$ seed.

Soil application of B. subtilis @ $2.5 \mathrm{~kg} / \mathrm{ha}$ mixed with neem cake @ $250 \mathrm{~kg} / \mathrm{ha}$ with the disease intensity of 34.3 PDI was not effective in managing the fruit rot disease. The highest root rot disease intensity (46.6 PDI) was observed in the control (Table 2). Meena (2016) reported the effectiveness of Pseudomonas fluorescens in the management of root rot disease of Coleus forskohlii. 
Table.1 In vitro inhibition of Colletotrichum capsici by Bacillus subtilis

\begin{tabular}{|l|c|c|}
\hline B. subtilis strains & $\begin{array}{c}\text { Mycelial growth of } \\
\text { C. capsici\% }(\mathbf{c m})\end{array}$ & $\begin{array}{c}\text { Inhibition zone } \\
(\mathbf{m m})\end{array}$ \\
\hline Bs1 & 3.4 & 14.6 \\
\hline$B s 2$ & 6.1 & 7.2 \\
\hline$B s 3$ & 4.2 & 10.4 \\
\hline$B s 4$ & 3.8 & 12.3 \\
\hline$B s 5$ & 5.6 & 8.1 \\
\hline Control & 8.8 & - \\
\hline \multicolumn{1}{|c|}{$C D(P=0.05)$} & 2.4 & \\
\hline
\end{tabular}

*Mean of four replications

Table.2 Effect of Bacillus subtilis talc based formulation on the management of fruit rot disease of chillies

\begin{tabular}{|c|}
\hline Treatments \\
\hline $\begin{array}{l}\text { T1- Soil application of } B . \text { subtilis @ } 2.5 \mathrm{~kg} / \mathrm{ha} \text { mixed with neem } \\
\text { cake @ } 250 \mathrm{~kg} / \mathrm{ha}\end{array}$ \\
\hline T2- Seed treatment with $B$. subtilis @ 10 g/kg seed \\
\hline $\mathrm{T}_{3-}$ Foliar application of $B$. subtilis @ $10 \mathrm{~g} / \mathrm{l}$ on 30 and 60 DAP \\
\hline $\begin{array}{l}\text { T4- Seed treatment with B. subtilis @ } 10 \text { g/kg seed + Foliar } \\
\text { application of B. subtilis @ } 10 \text { g/l on } 30 \text { and } 60 \text { DAP }\end{array}$ \\
\hline $\mathrm{T}_{5}$-Seed treatment with carbendazim @ $2 \mathrm{~g} / \mathrm{kg}$ seed \\
\hline $\begin{array}{l}\text { T6- Foliar application of carbendazim @ } 1 \text { g/l on } 30 \text { and } 60 \\
\text { DAP }\end{array}$ \\
\hline 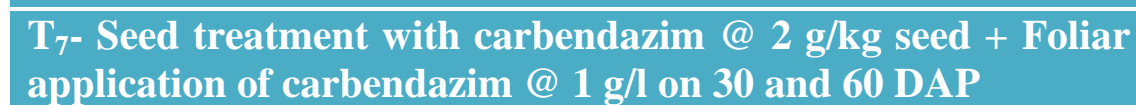 \\
\hline $\mathrm{T}_{8}-$ Control \\
\hline $\mathrm{CD}(\mathrm{P}=0.05)$ \\
\hline
\end{tabular}

\begin{tabular}{|c|c|}
\hline $\begin{array}{c}\text { Fruit rot } \\
\text { disease } \\
\text { intensity PDI }\end{array}$ & $\begin{array}{c}\text { Dry chillies } \\
\text { yield } \\
(\mathbf{t} / \mathbf{h a})\end{array}$ \\
\hline 34.3 & 1.97 \\
\hline 31.8 & 2.39 \\
\hline 27.5 & 2.65 \\
\hline 23.6 & 2.83 \\
\hline 32.3 & 2.14 \\
\hline 28.4 & 2.48 \\
\hline 24.7 & 2.71 \\
\hline 46.6 & 1.81 \\
\hline 2.8 & 0.16 \\
\hline
\end{tabular}

The values are mean of three replications

Table.3 Induction of chitinase activity upon treatment with B. subtilis formulation

\begin{tabular}{|c|l|c|c|c|c|} 
S. No. & \multicolumn{3}{|c|}{ Treatments } & \multicolumn{3}{c|}{ Chitinase activity (nmol GlcNAc/min/g) } \\
\cline { 3 - 6 } & & \multicolumn{3}{|c|}{ Days after inoculation with C. capsici } \\
\hline 1. & B. subtilis + C. capsici & 1 & 3 & 5 & 7 \\
\hline 2. & B. subtilis & $31.39^{\mathrm{a}}$ & $40.38^{\mathrm{a}}$ & $51.46^{\mathrm{a}}$ & $46.23^{\mathrm{a}}$ \\
\hline 3. & C. capsici & $27.58^{\mathrm{b}}$ & $31.26^{\mathrm{c}}$ & $42.83^{\mathrm{c}}$ & $38.27^{\mathrm{c}}$ \\
\hline 4. & Untreated Control & $28.41^{\mathrm{b}}$ & $34.87^{\mathrm{b}}$ & $46.71^{\mathrm{b}}$ & $41.26^{\mathrm{b}}$ \\
\hline
\end{tabular}

The values are mean of five replications.

In a column, mean followed by a common letter are not significantly different at 5\% level by DMRT. 
Table.4 Induction of $\beta$-1,3-glucanase activity upon treatment with $B$. subtilis formulation

\begin{tabular}{|c|c|c|c|c|c|}
\hline \multirow[t]{3}{*}{ S. No. } & \multirow[t]{3}{*}{ Treatments } & \multicolumn{4}{|c|}{$\begin{array}{c}\beta-1,3 \text {-glucanase activity } \\
(\mu \mathrm{mol} \text { glucose released/min/g) }\end{array}$} \\
\hline & & \multicolumn{4}{|c|}{ Days after inoculation with $C$. capsici } \\
\hline & & 1 & 3 & 5 & 7 \\
\hline 1. & B. subtilis + C. capsici & $14.83^{\mathrm{a}}$ & $27.35^{\mathrm{a}}$ & $38.91^{\mathrm{a}}$ & $29.72^{a}$ \\
\hline 2. & B. subtilis & $11.38^{\mathrm{b}}$ & $17.82^{\mathrm{b}}$ & $26.74^{\mathrm{c}}$ & $21.28^{\mathrm{c}}$ \\
\hline 3. & C. capsici & $12.64^{\mathrm{b}}$ & $18.53^{\mathrm{b}}$ & $31.46^{\mathrm{b}}$ & $25.81^{\mathrm{b}}$ \\
\hline 4. & Untreated Control & $9.12^{\mathrm{c}}$ & $12.53^{\mathrm{c}}$ & $15.93^{\mathrm{d}}$ & $13.81^{\mathrm{d}}$ \\
\hline
\end{tabular}

The values are mean of five replications.

In a column, mean followed by a common letter are not significantly different at $5 \%$ level by DMRT.

In addition to disease reduction, the dry chillies yield was also found to be increased in the effective treatment. The maximum dry chillies yield of $2.83 \mathrm{t} / \mathrm{ha}$ was recorded in seed treatment with B. subtilis @ $10 \mathrm{~g} / \mathrm{kg}$ seed followed by foliar application of B. subtilis @ $10 \mathrm{~g} / \mathrm{l}$ on 30 and 60 DAP. Seed treatment with carbendazim @ $2 \mathrm{~g} / \mathrm{kg}$ seed followed by foliar application of carbendazim at $1 \mathrm{~g}$ per litre on 30 and 60 days after planting recorded the dry chillies yield of $2.71 \mathrm{t} / \mathrm{ha}$. The dry chillies yield of $2.39 \mathrm{t} / \mathrm{ha}$ was observed in seed treatment alone with $B$. subtilis @ $10 \mathrm{~g} / \mathrm{kg}$ seed. In control, the lowest yield of 1.81 t/ha was observed (Table 2). Meena and Rajamani (2015) observed the plant growth promotion and enhancement of yield parameters in glory lily by dipping the tubers followed by foliar application of $P$. fluorescens talc formulation.

Synthesis and accumulation of PR proteins have been reported to play an important role in plant defense mechanisms. Chitinases (PR-3 protein) and $\beta$-1,3-glucanases (PR-2 protein) have been reported to associate with resistance in plants against pests and diseases (Van Loon, 1997). In general, fungal cells contain chitin and glucan as their cell wall constituents. The main mode of antagonistic activity of microbes is production of lytic enzymes which act on cell walls or organisms which have chitin and glucan as their cell wall component (Singh et al., 1999) and also through induced systemic resistance (ISR) in plant system. In the present study, the elevated levels of chitinase and $\beta-1,3$ - glucanase in plants treated with bioformulation containing endophytic bacteria against pathogen was observed. Chitinases are PR-proteins which hydrolyze chitin, a major cell wall component (3-10\%) of higher fungi. Chitinases cleave a bond between $\mathrm{C} 1$ and $\mathrm{C} 4$ of two consecutive Nacetyl glucosamine (GlcNAc) either by endolytic or exolytic mechanisms. The treatment with foliar application of $B$. subtilis formulation and challenge inoculated with pathogen led to the enhanced activity of chitinase compared to other treatments (Table 3 ). The maximum chitinase activity of 51.46 nmol GlcNAc $\min ^{-1} \mathrm{~g}^{-1}$ was observed in foliar application of $B$. subtilis talc formulation and challenge inoculated with pathogen. The chitinase activity was found to be increased up to five days after inoculation of the pathogen and thereafter declined. All the treatments were significantly different from control (Table 3). Meena et al., (2000) reported that $P$. fluorescens induced various defense compounds in groundnut.

Significant increase in $\beta$-1,3-glucanase activity (38.91 $\mu \mathrm{mol}$ glucose released $\min ^{-1} \mathrm{~g}^{-1}$ was observed in the treatment of foliar application of $B$. subtilis talc formulation and challenge inoculated with pathogen. B. subtilis treatment challenge inoculated with pathogen recorded higher levels of $\beta$-1,3-glucanase activity up to five days after inoculation of the pathogen and declined thereafter (Table 4). Elicitation of ISR in cotton by B. subtilis EPCO 102 with chitin led to the lowest bacterial blight incidence due 
to the induction of chitinase, $\beta$-1,3-glucanase, peroxidase and polyphenol oxidase (Rajendran et al., 2006). Ramyabharathi et al., 2012 highlighted the induction of defense enzymes $v i z$, chitinase and $\beta$-1,3-glucanase in tomato plants infected with Fusarium oxysporum f. sp. lycopersici by the biocontrol agent $B$. subtilis EPCO16.

Thus, in conclusion, the current study reveals the potential of talc formulation of $B$. subtilis in inducing the plant's own defense mechanism to suppress the fruit rot disease of chillies.

\section{References}

Boller, T. and Mauch, F. 1988. Colorimetric assay for chitinase. Meth. Enzymol, 161: 430-435.

Dennis, C. and Webster, J. 1971. Antagonistic properties of species groups of Trichoderma: Production of non-volatile antibiotics. Trans Br. Mycol. Soc, 57: 2539.

Manikandan, R, Saravanakumar, D, Rajendran, L, Raguchander, T. and Samiyappan, R. 2010. Standardization of liquid formulation of Pseudomonas fluorescens Pf1 for its efficacy against Fusarium wilt of tomato. Biological Control, 54: 83-89.

Meena, B, Radhajeyalakshmi, R, Marimuthu, T, Vidhyasekaran, P, Doraiswamy, S. and Velazhahan, R. 2000. Induction of pathogenesis-related proteins, phenolics and phenylalanine ammonia-lyase in groundnut by Pseudomonas fluorescens. J. Plant Dis. Protect., 107: 514-527.

Meena, B. 2016. Integrated disease management of root rot in Coleus forskohlii. World Journal of Pharmaceutical Research, 5: 1312-1317.

Meena, B. and Marimuthu, T. 2012. Exploitation of biocontrol agents for the management of jasmine wilt. South Indian Hort, 60: 187189.

\section{How to cite this article:}

Meena, B. 2018. Bacillus subtilis Mediated Systemic Resistance in Chillies against Colletotrichum capsici. Int.J.Curr.Microbiol.App.Sci. 7(05): 1542-1547.

doi: https://doi.org/10.20546/ijcmas.2018.705.182
Meena, B. and Rajamani, K. 2015. Biological control of leaf blight disease in Gloriosa superba using Pseudomonas fluorescens, Journal of Pure and Applied Microbiology, 8: 2579-2586.

Ongena, M. and Jacques, P. 2008. Bacillus lipopeptides: versatile weapons for plant disease biocontrol. Trends in Microbiology, 16: 115-125.

Pan, S. Q, Ye, X. S. and Kuc, J. 1991. Association of $\beta$-1,3-glucanase activity and isoform pattern with systemic resistance to blue mould in tobacco induced by stem injection with Peronospora tabacina or leaf inoculation with tobacco mosaic virus. Physiol. Mol. Plant Pathol, 39: 25-39.

Rajendran, L, Saravanakumar, D, Raguchander, T. and Samiyappan, R. 2006. Endophytic bacterial induction of defense enzymes against bacterial blight of cotton. Phytopathol. Mediterr, 45: 203-214.

Ramyabharathi, S. A, Meena, B. and Raguchander, T. 2012. Induction of chitinase and $\beta$-1,3-glucanase PR proteins in tomato through liquid formulated Bacillus subtilis EPCO16 against Fusarium wilt. Journal of Today's Biological Sciences: Research \& Review, 1: 59-66.

Rangaswami, G. 1972. Diseases of crop plants in India. Prentice Hall of India Pvt. Ltd. New Delhi, p. 520.

Singh, P. P, Shin, Y. C, Park, C. S. and Chung, Y. R. 1999. Biological control of Fusarium wilt of cucumber by chitinolytic bacteria. Phytopathology, 89: 92-99.

Van Loon, L. C. 1997. Induced resistance in plants and the role of pathogenesis-related proteins. European J. Pl.Pathol, 103: 753765 .

Vidhyasekaran, P. and Muthamilan, M. 1995. Development of formulations of Pseudomonas fluorescens for control of chickpea wilt. Pl. Dis., 79: 782-786. 